\title{
The Role of Culture in Implementing Lean Production System
}

\author{
Meiling Wong \\ Department of Industrial Engineering \& Enterprise Information, \\ Tunghai University, Taichung, Taiwan, R.O.C. \\ Department of Industrial Engineering \& Management, National Chinyi \\ Institute of Technology, Taipin, Taichung, Taiwan, R.O.C. \\ 12F,\#13, Jun-Ho St., Pai-Tun, Taichung, Taiwan, R.O.C. \\ email:mlwong@ncut.edu.tw Tel:886-1-4-24362803
}

\begin{abstract}
.
Culture is a powerful, latent, and often unconscious set of forces that determine both of our individual and collective behavior, ways of perceiving, thought patterns, and values. Organizational culture in particular matters because cultural elements determine strategy, goals, and modes of operating. Many international managerial theories or production methods work well locally, but can not receive expected result once they are practiced cross nationally. Although SDWT can be seen as an example of cultural adaptation of lean manufacturing system, yet little is known about the inefficiency caused by the cultural differences. The academic community has remained primarily dedicated to single culture and comparative research which is no more sufficient. Cultures are patterns of interacting elements. To decipher that pattern, we propose an analytical framework based upon the investigation on how Taiwanese enterprises cope with the cultural resistance to achieve expected goals.
\end{abstract}

\section{Keywords}

SDWT, lean production, organization culture

\section{Introduction}

Organizational culture, contained of common values, symbols, beliefs, and behaviors, comes down to a common way of thinking, which drives a common way of acting on the job or producing a product in a factory. These shared assumptions, 
beliefs, and values are implicit, yet they can make the difference (functional or dysfunctional) between a company that wins and loses (Goffee and Jones, 1998, p.14). Many international managerial theories or production methods work well locally, but can not receive effect as expected once they are cross nationally practiced.

In last twenty years, the process of Lean Production System globally learned and imported, originated from Japanese Toyota Motor, is a very good example. In order to have Lean Production System put through thoroughly, the SDWT (Self-directed Work Team) implemented on shop floor in North America is a typical case of culturally adaptive feature.

To date, the academic community, by itself, has remained primarily dedicated to single culture and comparative research (Hofstede, 1982; 1991; 1991a; Trompenaars, 1984; Hampden-Turner and Trompenaars, 1993; Joynt and Warner, 1996) which, while still necessary, is no more sufficient (Bartholomew and Adler, 1996). Culture conceived as essence and difference is a massive wheel reinventing itself (Holden, 2002, p.53), we can not simply generalize the entire world from one another. Cultures are patterns of interacting elements. If we don't have a way of deciphering that pattern then we may not understand the cultures at all (Schein, 1999). Thus constructing an analytical framework based upon the culturally adaptive features in investigating how enterprises cope with cultural resistance by adjusting their organization and methods to achieve expected goal is an important research direction.

The purpose of our research is to clarify the culturally adaptive features on site in Taiwanese enterprises with Lean Production implementation. We start out with reviewing the previous research of Lean Production and culture. And using Hofstede's national culture dimensions and study of Japanese enterprises in Taiwanese to derive out the sense of problem of how Taiwanese enterprises cope with cultural difference with their organizational mechanism in Lean Production System implementation. Then on top of this base, we apply Schein's theory of three levels of corporate culture to set up our analytical framework for culturally adaptive features on site in Taiwanese enterprises with lean production system implemented, also have our case study of two Taiwanese enterprises carried on. At the end of our paper, we conclude with important findings and managerial implication from the research.

\section{Lean Production System and Culture}

Leading the global learning fever of lean production, the book of "The Machine That Changed the World" by Womack, Jones and Ross in 1990, was the first to use the name of Lean Production System. It introduced ideas such as Just In Time, Kanban, Jidoka, quick-switching in modes and lines, and maintenance, etc. Moreover in recent years, concepts like "lean manufacturing", "lean thinking", and "The Toyota Way" in North America keeps fermenting among nations (Womack and Jones, 1996; Shah and Ward, 2003; Liker, 2004). 
Lean Production System has been one of the competitive advantages for Japanese enterprises, its cultural element underneath (Recht and Wilderom, 1998), well-known by academy and practice fields which may not exist in other countries or enterprises. While during the process of being "lean", due to their different national or organizational cultures, enterprises of nations who intend to put through Lean Production system in their organizations appear to have various culturally adaptive mechanisms SDWT in North America is seen as the adaptive system accordingly as needed (Wilson \& Grey-Taylor, 1995; Janz, 1999; Rafferty \& Tapsell, 2001). SDWT works in organizations as to bring out the advantage by strengthening collective power and avoiding disadvantage of individualism. Nevertheless its effect is still limited to the cultural constraint.

National culture plays an important role in constructing the corporate culture (Adler and Jelinek, 1986; Doktor, 1990; Hofstede, 1991; O'Conner, 1995), where its impact is reflected in response to the limit on the organization from external environment and appeared on the human resource management with respect to the employees' psychological level and preference. In cross national business or cooperation, the inconsistence of national cultures increases the difference of the organizational cultures (Oudenhoven, 2001), which indirectly hinders the transfer of managerial modes or production system (Yoshiaki, T; M. Hayashi, and K. Hidaka, 2000).

Hofstede and Bond (1988, p.10-16) revealed that national cultures differ mainly along four dimensions: Power distance, Individualism/Collectivism, Masculinity/ Femininity, and Uncertainly avoidance. Further a fifth dimension of Confucian Dynamism (later is revised to long term versus short term orientation in Hofstede, 1994) to distinguish countries of the teaching of Confucius. Also in their national culture comparison, Taiwan and Japan have relatively closer national culture features, especially in the dimensions of power distance and Confucian Dynamism (Hofstede and Bond, 1988, p.12-13, exhibit.2). This may be explained by their historical connection.

However Japanese enterprises in Taiwan including small group activities have very strong features of Japanese production system on site, which seem obviously different in comparison with North America and China (Liu, 1996, 2000). We therefore would like to propose that Taiwanese enterprises have the 'cultural interface' and in turn develop out the agilely adaptive Lean Production System which is totally different from SDWT, and have its mechanism verified through out our case study.

\section{The Analytical Framework of Culturally Adaptive Features}

In this article, we define culturally adaptive features as: the phenomenon appeared or adaptive behavior adopted during implementation of managerial styles or production systems by the organization in coping with cultural difference in terms of value points or ways of thinking.

For decades, many researches contribute the economy success of East Asia countries to their common background of Confucianism (Hofstede \& Bond, 1988; Ruttan, 1995; Yeung \& Tung, 1996; Fang, 2001). In Hostede's research (1994), the 
results point out that long term orientation is correlated with national economic growth showing that what led to the economic success of the East Asian economies during the past 25 years is their populations' cultural stress on the future-oriented values of thrift and perseverance. Jones and Davis (2000, p.28) also claim that those characteristics normally associated with the positive pole of the Confucian dynamism dimension, including the focus on hard work and perseverance should be the concepts of 'face' and reciprocation, and concerns for traditions and fulfilling social obligations (Hofstede 1994, Hofstede and Bond, 1988). It seems this long term versus short term orientation lies underneath the motives is what makes it most different between Japanese and Taiwanese behavioral modes.

We apply Schein's (1992) three levels of organizational cultural theory to elaborate our analysis. Schein believes that there are three levels of organizational culture, they are: Level one--- artifacts: they are visible organizational structures and processes, such as the décor, and the climate, but hard to decipher. Level two--espoused values: strategies, goals, philosophies, which provide deeper level of thoughts and perceptions that drive the overt behavior. And Level three---shared tacit assumptions: they are unconscious, taken-for-granted beliefs, perceptions, thought and feelings, where the value system is from (Schein, 1999, p.15-20).

Horsley and Buckley (1990) describe the Confucian 'work ethic', introduced to feudal Japan through Chinese and Korean models, as a comprehensive social code governing relationships, respect for authority and conformity to the rule of law. People of these countries thus regard work not as a hardship but as a positive lifeasserting activity. They all are diligent, and value collective harmony in general, yet there is difference in their behavioral modes in terms of long-term /short-term perspectives.

The Tanaka formula (Tanaka, 1992) for adding value to its people, products and processes, based on the traditional Japanese cultural trait of continuous improvement or Kaizen, is a model for achieving business excellence. When Kaizen is adopted as a personal philosophy, it becomes a lifetime process of continuous personal development (Cartwright, 1999, p.14). In contrast with this long-term perspective, Taiwanese core values are deeply influenced by Chinese culture, which are inclined to characteristics of self-centered, think highly of "guanxi" and "face", ignore accuracy, and care for benefit at the moment, etc. (Smith, 2000, p.7, 31, 51, 75). In such high-context culture country, trust and commitment to another is secured by the potential damage to one's social position or face, which may result from failing to honor exchange obligations ( $\mathrm{Yi}$ and Ellis, 2000). Guanxi may bring personal gains to individuals, vital resources and cost savings to the organizations. But these benefits are often achieved at the expense of other individuals (Fan, 2002).

Overall speaking, Taiwanese enterprises have the cultural approach of short-term vision that drives individual self conservation value in contract with Japanese enterprises' long-term vision that drives group's self realization value. Japanese and Taiwanese enterprises flaunt different value system. While implement Lean Production System, Taiwanese enterprises need to conduct the cultural adaptation by taking an alternative way and organization to cope with the difference, which is the basic assumption of our research. 


\section{Case Study}

Both of the enterprises as our case study with listed companies are globally wellknown and leading companies of Taiwanese optical and bicycle industries. They actively promote and implement Lean Production System in recently years and receive quite achievement. The Asia Optical was established in 1981, located at Taichung, with employees of 1,146 people. Their main products are optical lenses, microscope, aiming device, laser measurement of distance and components and parts. etc. Merida was established in 1972, located at Chanhwa, with employees of 888 people. Their main products are high class bicycle, superb bikes, exercise bikes, auto bikes and magnesium-alloyed computer shells, etc. Our research consisted of indepth person-to-person interviews of 2-3 hours duration each with two informants per enterprise (thus, a total of 4 interviews).

In its 25-year business, the Asia optical continuously focuses on trading with Japanese enterprises as their major customer, and has been strongly influenced by Japanese style. Those strongholds co-invested with Japanese enterprises in China are particularly worldwide known (Liu, 2003). The most noticeable reform of Japanese Canon in last ten years has also had direct impact on the Asia Optical. In June 2002, the Asia Optical announced to promote Toyota Production System with determination in hiring the former executive of Japan Canon, Mr. Nishimae as the consultant and the term of "production renovation" used which was also originally from Japan Canon. The first year, they started from the important cities of production where Chinese Business grouped and received great achievement after fifteen months. One after another, the activities were continuously taken place in Taiwan on Sept. of 2003, Philippine on Feb. of 2004, and in Burma on July of 2005. Whenever and wherever there is activity being held, the President, Mr. Yi-Ren, Lai always comes forward to take the lead and starts out from conscious revolution. President Lai as the leader, along with his crew, gives spiritual lecture to express their determination of carrying out through to the end. In order to put into effect, the Asia Optical establishes the general office with sub units as the regional offices who are in charge of promotion. All regional office, being supportive for each business promotion team, holds competition activities and renovation conference periodically. To create the climate for inspiring improvement thoughts, there is no hierarchy but treating each other as classmates. At the meantime, the role of middle management in the promoting teams switches from a traditional supervisor to a helper to assist the employees in putting the improvement thoughts into practice.

Merida has also tried to improve their production though they did not have much history with Japan. For the sake of leading bicycle industry and grouping ATeam, they implement TPS in March of 2003 under the instruction of the president of Kuozui Motors, Takehiko Harada. The shop floor improvement is planned in accordance with the present condition of A-Team member and its whole future requirement, which is discussed and decided by A-Team office that also does plans for the yearly performance target. The improvement project contains educational training courses, monthly instruction from Kuozui's TPS consultant team, recruitment of factory seed talent personnel, interactive learning forum, and result exhibition, etc. Either internally or externally, Merida actively participate A-Team's 
semi-year result presentation, started from one Team and later expanded into six Teams. In last three years, time required of material input to bike frames has reduced from 6 days to 2 days, material stock has been cut down to $1 / 5$, and online stock has been reduced to one third, which in turn has brought up $30 \%$ of the production efficiency. Mr. Suon-Tzu Tsen, the president of Merida who is also the vice president of A-Team, has expressed to both inside and outside with his strong vision and will in putting though to the end. He spoke with satisfactory: it was easy to make progress from grades of 60 to 90 . But it gets tougher when we intend to move forward. Nevertheless we believe that improvement on site should never end.

Merida requires a whole crew participation, which mainly contains: evaluating with performance award to encourage employees' learning motivation, combining promotion channels while take a long-term foster and training to those who are creative and active, and for monthly performance awards that belonged to individuals and groups, Merida thinks it is necessary to promote multi-skilled operators and process production. When targets of various stages achieved, Merida begins to pay more attention on nurturing the organizational environment and less emphasis on immediate result and effect of improvement, and incline to a gradual decrease for individual incentive.

During Lean Production System implementation in these two enterprises, in contrast with the basic assumption and analytical framework raised by our research, there are at least two significant differences. One is the short-term individual or team incentive that exists in Merida and its necessity is emphasized. The other one is the incentive system and organizational goal are gradually adjusted as needed. The proportion of short-term individual or group incentive is progressively decreased when Lean Production System has been put into effect and making improvement.

Without lifetime employment, seniority-based wages or other long-term human resource incentive system, the short-term individual incentive system is prevailing in lots of Taiwanese enterprises (Liu, 1996). In the beginning stage of Lean Production System implementation, it is understandable to have systems like short-term incentive system. And Merida's adjustment of incentive system and organizational goals may be seen as an indicator of the degree of value system change. Obviously, being long-term influenced by Japanese enterprises, the employees of Asia Optical has already gone through this stage. It seems that having the organizational climate of long-term prospect and vision is quite enough to achieve the goals. This kind of effort devoted shows the value system change in thinking highly of groups and selfrealization of the operators driven by long-term vision. This change is helpful for fermenting the manufacturing site with long-term vision to carry on continuous improvement for long-term incentive effect, which not only enables continuous learning, but also indirectly create the atmosphere needed for mutual assistance between shop floor teams. Being relatively passive, Taiwanese enterprise shop floor cares more for "face", with the supporting mechanism of comparing and learning, the external experts and high rank of unit in charge are able to achieve the goals of improving mutual assistance ability within teams or collaborative capability cross departments.

In conclusion, there exists degree of difference among Japanese enterprises, Asia Optical, and Merida in flaunting their values of motives, diligent, and think highly of group harmony. The culturally adaptive organization and method in 
enabling self-realization on site seems also cause the quality change of the flaunted value system. The top manager's participation in person, help from external experts, and higher rank of unit in charge and so on do have important effect. At the meantime, if Taiwanese enterprises could turn themselves toward to the flaunted value system driven by long-term vision, short-term individual incentive system will gradually fade away.

\section{Conclusion and Implication}

The characteristic of Lean Production System is that it contains not only visible skills or methods (task side), but also the organizational collaborative factor between people (human side), which explains why simply duplicate it cannot receive the same effect. There is the need for cultural adaptation. Our study shows that since Japanese and Taiwanese enterprises have different flaunted value system, it is required to have cultural adaptation conducted while implementing Lean Production System. In other words, it is necessary to take a different organization and method to cope with it so as to reserve the spirit of Lean Production System, have it put through thoroughly, thus in turn the competitive advantage with positive cycle can be derived.

Specifically speaking, there are four culturally adaptive features for the manufacturing site in Taiwan when implementing the Lean Production System:

1) The top manager participates in person to expresses his strong ambition and vision. Top managers who take part personally and express their determination in solid action to set up good environment or atmosphere for competition can break up the conception of "I" of being selfness and help to drive the change of value system with long-term vision.

2) Help from external experts and raise higher rank of unit in charge seem to be the common organization type and method, in combining with the atmosphere driven by top managers (discussed above) and assorted mechanism of both competition and inspecting and learning can protect it from being perfunctory, which is an indispensable organizational competency in refining the Lean Production System implementation.

3) Short-term individual or group incentive is still necessary. When there is no either lifetime employment, seniority-based wages or any other long-term human resource incentive system, the short-term incentive system is still needed, especially at the beginning stage.

4) The proportion of short-term individual or group incentive may be gradually decreasing or fading away while Lean Production System gets refiner and more practicable. This can be seen as an indicator for the degree of value system change.

This research found that national culture has significant impact during the process of Lean Production System implementation in Taiwanese enterprises. Yet there are two more subjects required more attention. One is the generalization problem of this article. Do all Taiwanese enterprises who have successfully implemented Lean Production System have similar criterions? Another one is that when a complete Lean Production System across product development and collaborative system is implemented, more organizational and wider cultural levels 
will be involved. Will culturally adaptive features still be the same in that situation? We shall be delighted to share and work with scholars who are interested in further relevant research.

\section{References}

Adler, N.J. et al (1986). "From the Atlantic to the Pacific Century: Cross-Cultural Management Reviewed". Journal of Management, 12(2), pp.295-318.

Bartholomew, S. and Adler, N. (1996). Building networks and crossing borders: the dynamics of knowledge generation in a transnational world. In: Joynt, P. and Warner, M. Managing across cultures: Issues and perspectives. London: International Thompson, pp.7-32.

Cartwright, J. (1999). Cultural Transformation, nine factors for improving the soul of your business. London: Pearson Education LTD.

Deal, T and Kennedy, A. (1982). Corporate Cultures. Addison-Wesley, Reading, MA.

Doktor, R H. (1990). "Asian and American CEOs: A Comparative Study". Organizational Dynamics, Vol. 18, No.3, pp.46-56.

Fan, Y. (2002). "Questioning guanxi: definition, classification and implications". International Business Review, 11, pp.543-561.

Fang, T. (2001). "Culture as a driving force of interfirm adaptation: A Chinese case". Industrial Marketing Management, 30, pp.51-63.

Goffee, R. and Jones, G.. (1998). The character of a corporation. $2^{\text {nd }}$ ed. London: Profile Books LTD.

Hampden-Turner, C. and Trompenaars, F. (1993). The seven cultures of capitalism: value systems for creating wealth in the United States, Britain, Japan, Germany, France, Sweden and the Netherlands. London: Judy Piatkus.

Hofstede, G.. (1980/1991). Culture's consequences: International differences in work-related values. Beverly Hills, Ca: Sage Publications.

Hofstede, G. (1982). "Intercultural cooperation in organizations". Management Decision, 20. pp.53-67

Hofstede, G.. (1991a; 2003). Culture and organizations: Intercultural cooperation and its importance for survival - software of the mind. London: McGrawHill.

Hofstede, G. (1994). "The business of international business is culture". International Business Review, Vo. 3, No. 1, pp.1-14.

Holden, N. J. (2002). Cross-cultural management, a knowledge management perspective. London: Pearson Education Ltd., pp.53.

Horsley, W. and Buckley, R. (1990). Nippon. London : BBC Books.

Janz, B. (1999). "Self-directed Teams in IS: Correlates for Improved Systems Development Work Outcomes". Information \& Management, 35, pp.171-192.

Joynt, P. and Warner, M. (1996). Managing across cultures: Issues and perspectives. London: International Thompson. 
Jones, G.K., and Davis, H. (2000). "National culture and innovation: implications for locating global R\&D operations". Management International Review, vol.40, 00.11-39.

Liker, J. K. (2004). The Toyota Way, 14 management principles. New York, U.S.: McGraw-Hill Books Company.

Liu Ren-Jye. (1996). "A Study of Japanese Management System of the Japanese Affiliated Companies in Taiwan and China," Journal of Economics \& Business Administration (in Japanese), Edited by Kobe University, Vol.174 No.1, pp.3752.

Liu, Ren-Jye. (2000). "International Division of Labor and Japanese Production System," in Munakata, M. Nuki, T. and Sakamoto K., eds. Contemporary Production System (in Japanese), Kyoto: Minerva, pp.218-237.

Liu, Ren-Jye.(2003). "An Empirical Study of Strategic Alliances between Taiwanese and Japanese Enterprises in Mainland China." Journal of Asian Business. 19(3): $71-94$.

Martin J. and Meyerson, D. (1988). Organizational Cultures and the Denial, Chenneling and Acknowledgement of Ambiguity and Change, pp.93-125. John Wiley \& Sons, Chichester.

Nathan, J. (1999). Sony: The private life. London: HarperCollins.

O'Connor, N.G. (1995). "The Influence of Organizational Culture on the Usefulness of Budget Participation by Singaporean-Chinese Managers". Accounting, Organizations and Society, Vol. 20, No. 5, pp.383-403.

Oudenhoven, J. P. (2001). "Do Organizations Reflect National Cultures? A 10 nation study". International Journal of International Relations, 25, pp.89-107.

Rafferty, J and Tapsell J. (2001). "Self-Managed Work Teams and Manufacturing Strategies: Cultural Influences in the Search for Team Effectiveness and Competitive Advantage". Human Factors and Ergonomics in Manufacturing, Vol. 11 (1), pp.19-34.

Recht .R. and Wilderom, C. (1998). "Kaizen and Culture:on the Transferability of Japanese Suggestion Systems". International Business Review, 7, pp.7-22.

Shah, Rachna and Ward, Peter T. (2003). "Lean manufacturing: context, practice bundles, and performance," Journal of Operations Management, Vol.21, Issue2, pp.129-149.

Schein, E.H. (1992). Organizational Culture and Leadership, $2^{\text {nd }}$ ed. C.A.: JosseyBass, San Francisco, pp 15-20.

Schein, E.H. (1999). The Corporate Culture Survival Guide. C.A.: Jossey-Bass, San Francisco.

Smith, A.H. (2000). Chinese character. H.K.: Joint Publishing Co.

Tanaka, K. (1992). Building a New Japan. Tokyo: Simul Press,.

Trompenaars, F. (1984). The organization of meaning and the meaning of organization - a comparative study on the conceptions and organizational structure in different cultures. $\mathrm{PhD}$ thesis, University of Pennsylvania.

Wilkins, A. L. and Ouchi, W. G. (1983). "Efficient Cultures: Exploring the Relationship Between Culture and Organizational Performance". Administrative Science Quarterly, Vol. 28, pp.468-481. 
Wilson.J.R and Grey-Taylor, S.M. (1995). "Simultaneous Engineering for Selfdirected Work Teams Implementation: A Case Study in the Electronics Industry". International Journal of Industrial Ergonomics, 16, pp.353-365.

Womack, James, Daniel Jones and Daniel Ross, (1990). The Machine That Changed the World. N.Y.: Rawson Associates, Macmillan.

Womack, James, and Daniel Jones, (1996). Lean Thinking. N.Y.: Simon and Shuster.

Yeung, I. Y.M., and Tung, R.L. (1996) "Achieving Business Success in Confucian Societies: the importance of guanxi (connections)". Organizational Dynamics, Autumn, pp.54-65.

Yi, L.M., and Ellis, P. (2000). "Insider-outsider perspectives of guanxi". Business Horizons, Jan-Feb., pp.25-30.

Yoshiaki, T., M. Hayashi, and K. Hidaka. (2000). International Transfer of Management Style (in Japanese), Tokyo: Chuuo University Press.

Printed in the United States of America 